Van der Watt, $\mathrm{G}^{1}$

University of the Free State

\title{
Recent developments and challenges in understanding the Dutch Reformed family of churches' missional identity and calling
}

\begin{abstract}
The article focuses on recent developments in and discourses on the missionary or missional calling and identity of the Dutch Reformed Church Family. The historical legacy of an ideological missionary approach and involvement, the reaction of younger sister churches, important workshops and declarations, the struggle for unification as well as the post-Apartheid context, contributed significantly to this process of understanding its calling to witness and service. It is a continuing discourse which is currently also impacted by a new understanding of "being" missional congregations.
\end{abstract}

In October 2006 the domestic family of Dutch Reformed Churches, the Dutch Reformed Church (DRC), the Nederduitse Gereformeerde Kerk in Afrika (NGKA), the Reformed Church in Africa (RCA) and the Uniting Reformed Church in Southern Africa (URCSA), formed a united structure for service and witness. It is called the United Ministry for Service and Witness. This newly formed structure adopted an important declaration on its calling to service and witness in unity ${ }^{2}$. This declaration is a significant development in the continuous theological reflection on the church's missionary (missional?) identity and calling.

This article aims to briefly tell the story of how and on what theological basis the domestic family of DRC Churches came to the formation of a united ministry for service and witness. The legacy of more than two centuries of the DRC's mission policy and practical involvement in mission and diaconal service, resulting in the younger churches' struggle for independence and the family's struggle for reunification, has had a significant impact on the process. Some recent developments and specific events in the South African post-apartheid context however, also played a major role. In the successive stages of the process of reflecting on the church's missionary identity, calling and practice, the Bible has been read differently, emphasising different texts and hermeneutics. Some important declarations on the church's understanding of its calling to witness and service also guided the process. From a new angle the current discourse on "missional congregations" is also contributing significantly to the discourse on defining the church's missional calling and identity.

\section{BRIEF HISTORICAL PERSPECTIVE ON THE DUTCH REFORMED CHURCHES' INVOLVEMENT IN MISSION AND SERVICE}

1.1 An important feature of the DRC is its immense historical involvement with mission work in Southern Africa (Cronjé 1981, Crafford 1982). The planting and the growth of several churches

1 Dr Van der Watt is research fellow and lecturer in the Department of Missiology, Faculty of Theology,

University of Free State and is Secretary for Witness, DRC Free State

2 See document attached below 
in Southern Africa can be directly linked to the historical mission involvement of the DRC: domestically there are the Nederduitse Gereformeerde Kerk in Afrika, the Uniting Reformed Church in Southern Africa and the Reformed Church in Africa, and abroad there are the Church of Central Africa Presbyterian (the Nkhoma-Synod in Malawi as well as the Harare and Zambia Synods of the CCAP), the Reformed Church in Zambia, the Reformed Church in Zimbabwe, the Dutch Reformed Church in Botswana, the Church of Christ amongst the Tiv (Nigeria), the Reformed Church in East Africa (Kenya), the Igreja Reformanda em Mozambique and the Swaziland Reformed Church (Cronjé 1982). There are also established churches in Namibia and Lesotho, but they form part of the DRC, NGKA and URCSA. For more than a century missionaries sent out by the DRC contributed sacrificially in establishing many mission schools, special institutions for the deaf and the blind, hospitals, developmental- and agricultural projects, theological training institutions and so forth.

However, while celebrating the contribution of the DRC missionaries, the enormous contribution indigenous members - the elders, evangelists, ministers and especially women of the different churches made in building these churches, should never be forgotten. Many of these mission areas - so we increasingly discover - were "opened up" by pioneers sent out by the erstwhile NGKA and the Dutch Reformed Mission Church, as well as evangelists from the young sister churches in our neighbouring countries (Crafford 1991). Some of those pioneer missionaries even started working years before the DRC actually became involved by officially sending out missionaries to these areas.

A family of independent churches in southern and central Africa evolved, with historical and confessional ties, sharing a joint tradition and calling. At the height of the DRC's mission involvement with these sister churches, a Federal Council of Dutch Reformed Churches was established in 1964, expressing the concept "family of churches" as a federal bond between independent churches. For several reasons, like perceived paternalistic trends and the hampering of the domestic reunification, the existence of this council has increasingly been questioned. It stopped functioning in the late seventies.

1.2 The DRC is also known for the major role it played in caring for the poor ("Armesorg") and other forms of compassionate services throughout the 20th century (Van Aarde 2002:411-419). Many special institutions for the blind, the deaf, orphanages, old age homes, etc. were built and different forms of social services rendered. Towards the end of the century the DRC could be regarded as one of the largest providers in social services in South Africa - next to the state probably the largest social service provider! This work became institutionalised. Organisations for delivering effective diaconal services were formed and it was done in close cooperation with and supported by the government.

1.3 The development of the younger churches' own mission and diaconal services were in a sense restricted; as objects of service and witness they mostly depended on the work done to them by the "mother church". The spontaneous witness and diaconate done by members in local congregations of the younger churches, resulting in the rapid growth of these churches, were also not recognised as such. Some wonderful institutions for orphans, the deaf and blind, the training of social workers, etc. were established by the diaconal services of the Dutch Reformed Mission Church, for instance (Botha 1986:35-53).

1.4 Despite all the good work, this very contribution in service and witness has eventually been driven by the ideology, which became known as apartheid. At some stage it was even blatantly called "our mission policy of apartheid", for instance in booklets and articles written by the 
Mission Secretary of the DRC Free State, rev JG Strydom, and officially distributed by this synod (Strydom 1939, 1946). Many dissertations have been written on the role the mission policy, which was adopted by the Federal Mission Council in 1935, played in the DRC's theological justification of apartheid. One example was how, under the influence of the 19th century German ("Volkskirkliche") missiology, the text of Matthew 28:16-21 - the so called great commission to go to the nations - has been interpreted to mean that separate, indigenous churches must be planted for each people group (Robinson 1986:86-101). Other texts that played a major role in this "Apartheid Bible" (Loubser 1987, Kinghorn 1986) were Genesis 1:25, Deuteronomy $32: 8$ and Acts 17:26. These texts were read as unchangeable "orders of creations" or "laws of nature", commanding the separateness of nations and therefore also of the different "Volkskirche" (Adonis 1986:78-81). The so called "daughter churches" were established with the ideal of being guided and supported by the so called "mother church" into separate, independent and indigenous churches.

The same applies to the DRC's compassionate service during the 20th century. This work focussed mainly on the alleviation of poverty and the social uplifting of the Afrikaner people, often excluding people of other races. It became customary in the DRC to understand compassionate service to be work done amongst the "white" members of the DRC and the diaconal and social work amongst black people has been called "mission".

1.5 This approach in mission and service lead to a reaction by the younger churches, especially during the latter half of the 20th century. The Sharpeville Massacre (1960) and the ensuing debates and church struggles, questioned and criticised this apartheid hermeneutic, especially in the mission policy of the DRC. The younger churches struggled for independence and pushed for political, social and cultural liberation. The mission policy of the DRC and the role missionaries played were increasingly questioned. Missionaries had to withdraw from the mission field in large numbers. The history of many different decisions by younger churches, the formulation of different documents, a "status confessionis" (1982) and even a new Confession of Belhar (1986) by the erstwhile Dutch Reformed Mission Church, are examples of this struggle against a mission policy that kept churches separate and dependent. The mission policy of the DRC had to be revisited. The baggage of the ideological understanding of mission (witness) and diaconal services had to be shed.

\section{WORKSHOP ON "WHAT IS MISSION" - 1986}

2.1 A Workshop on mission, convened at the University of the Western Cape in 1986, played an important role in this process of coming to a new understanding of mission (Robinson and Botha 1986). Representatives of several churches in the DRC-family (domestic and abroad) participated in this historical workshop. The aim was to come to a joint understanding of what mission entails. The discussion was frank. Amongst others, JC Adonis of the Dutch Reformed Mission Church fundamentally questioned the mission policy of the DRC and how it has been implemented in practice. In another keynote speech David Bosch gave a principled definition of mission. He emphasised mission in a kingdom perspective. By kingdom he meant God's involvement with the whole of creation, working towards comprehensive peace (shalom). In explaining this, he gave an exposition of Luke 4:18-19: "good news for the poor... the year of the Lords favour." The church's mission is flowing forth from and is partaking in the missio Dei - God's mission and action to realise shalom. All the mission ministries of the church are facets of this missio Dei and are constantly driving the church to cross boundaries of geography, religion, culture, ideology, social class, language, race, etc. Crossing boundaries, and not setting boundaries, like 
in the previous understanding of mission, became the new principle. The participants of the conference eventually formulated a joint working definition of mission. The church's mission (mission ecclesiae) flows from the realization that mission is first and foremost God's mission (missio Dei) and that the churches' calling to a holistic witness (marturia) should include the following dimensions: proclaiming the Word (kerugma), acts/services of love (diakonia), the forming of a new community of love and unity (koinonia), the zeal for a just society (dikaioma) and worship (leitourgia). It was also accepted that the integrity of mission depended on it being done in unity - the reunification of at least the domestic family of Dutch Reformed Churches was accepted as an urgent goal (Robinson and Botha 1988:62).

After the events of 1986, the DRC entered a period of debate and reflection, culminating in a comprehensive declaration on Church and Society in 1990 (Church and Society 1990). The church confessed its role in providing a biblical basis for apartheid and its active participation in the implementation and maintenance of this ideology, as sin. The DRC committed itself to a process for the reunification of the DRC Family. Its own mission policy was adapted to include the 1986 workshop's formulation. A period of withdrawal from the traditional mission fields resulted in the end of what some would call a specific "colonialist" mission era.

2.2 In the early nineties the South Africa society changed dramatically. In 1994 the new South African democracy was born. In that same year the Nederduitse Gereformeerde Kerk in Afrika and the Dutch Reformed Mission Church merged to form the Uniting Reformed Church in Southern Africa. However, several congregations of the NGKA, especially in the Free State and Northern Cape, decided to exclude themselves from the unity process and to continue the NGKA. This led to a period of prolonged tension, disputes about the existence of the NGKA and court cases about church buildings. The status of the Belhar Confession as prerequisite for the unity process became a point of dispute. The Reformed Church in Africa formulated the Laudium Declaration (1990) on its reformed, evangelical identity, being a missionary church in its own predominantly Hindu and Muslim context. Real reconciliation will not come overnight; deep schisms, distrust and wounds of the past still had to be healed. How to create space for different identities within the one church became an important question. The struggle for unity would take much longer than expected. As sister churches on a pilgrimage to unity (Nel and Du Toit 2007) the DRC Family still has to properly deal with the sadness and pain of the legacy of apartheid.

2.3 Towards the end of the 20th century it became clear that a new era has dawned. The old mission paradigm began to shift (Van der Watt 2003:224, Saayman 2003:194-212). In a recent overview on the DRC's mission history, Saayman dealt with the successive eras in the DRC's mission history from a social history point of view (Saayman 2007). The focus shifted from institutionalisation (work done by synods or institutions for diaconal service) to the witness and the diaconate of local congregations (Van Niekerk 1997:408-416). Congregations were again recognised to be the primary agent for service and witness.

Since the dawn of the "new" South Africa in 1994, the world opened to many congregations of the DRC. Many members could again travel abroad; thousands chose to emigrate. The focus in many congregations shifted to world mission, to the "unreached" peoples. Para-church mission organisations facilitating this shift mushroomed during the nineties and early years of the first decade of the new millennium. Acts 1:8, especially the reference to the "ends of the earth", became the dominant text. Could this be seen as an escape from the realities and challenges of the southern African context? Was this a brief interlude? It coincided with the growth of newPentecostalism and Charismatic churches and the decrease in membership of most mainline churches - especially those within the reformed tradition. The DRC had to redefine and re- 
establish its own identity and calling as church within the South African context - now as a much more vulnerable church that lost its previously powerful and beneficial position.

The DRC increasingly identified itself to be part and parcel of the South African context a context of poverty, HIV/Aids and other diseases, different dimensions of suffering and discrimination, violence, crime, the urgent need for reconciliation in the country, ecological deterioration, etc. - posing real challenges to the church (Meiring 1989, Kritzinger 2002). In 1998 the General Synod of the DRC established a task team to specifically focus on reconciliation, poverty and HIV and Aids (the so called "VAM Kommissie") and this lead to the year 2001 being called the "Year of Hope" as well as some important declarations on the Dutch Reformed Church's calling in 2002 and 2004 (Van der Merwe 2004:428-439). The DRC deliberately ventured to understand its existence in terms of its calling in the southern African contexts; the 2002 declaration on its calling ends with a hopeful reaffirmation: "Ons het ' $\mathrm{n}$ Here. Ons is hier. Ons is sy kerk." ("We have a Lord. We are here. We are his church"). The DRC committed itself to making a contribution towards the healing of the land, but this time round in a more humble way. It realised that these challenges called for a united venture - the DRC would not be able to take up the challenges on its own. Mission partnerships and "unity in mission and mission in unity" (Bosch 1991:463-467) became important facets in the understanding of the calling to service and witness.

\section{JOINT STRUCTURE FOR WITNESS}

3.1 After a tedious process of negotiation and consultation, a joint structure for witness was formed in 2003. The URCSA, RCA and the DRC joined their witness activities in the General Commission for Witness of the Dutch Reformed Family of Churches. The NGKA initially only participated in observer status. The formation of this body was a breakthrough - whilst the churches still hesitantly discussed the options for unification, the witness ministries already formed a united structure, taking over responsibility for the witness agendas of the participating churches. This newly formed united body arranged an important workshop at Stellenbosch on the eve of Pentecost 2004. Representatives from many parts of Africa: Nigeria, Malawi, Zambia, Zimbabwe, Mozambique, Botswana, Namibia, Swaziland, Lesotho and South Africa reflected together on "our calling to witness in and from Africa today". The workshop declared: "We experienced deep joy in our fellowship with one another, in the presence of God, knowing that we have many Christian brothers and sisters in Africa. We were blessed and challenged through our diversity by one another's stories and perspectives. We also shared the pain, the affliction and the groans coming to us from various local contexts on the continent of Africa". This conference intentionally built on the 1986 workshop on "What is mission?" (Robinson and Botha 1986), listened anew to one another, reflected on the shared calling to witness in unity and the clear need for real hope in and from Africa.

Critical papers were read, on the role and plight of women (a gender sensitive reading of texts), the task of theological training, the role of local congregations, the growth, but also the struggles of the church in Africa in the face of poverty, corrupt governments, civil wars, HIV and Aids, etc. The task of carefully discerning the African context was stressed. The calling to a public witness, partnerships and unity in mission (Pauw 2004) were underlined and especially what it meant to witness about hope in and from the African soil (Botman 2004). Rian Venter, then lecturer in Lusaka, presented a keynote paper on a reformed understanding of mission in an African context (Venter 2004). He challenged the meeting to come to a consistent Trinitarian understanding of ecclesiology and mission. The texts that were mostly considered during these deliberations were John 17 and 20, as well as Ephesians 4 - texts that focussed on the Trinity and 
unity. An extensive declaration on "our calling to witness in and from Africa" was formulated by Johan Botha, assisted by Piet Meiring and Gideon van der Watt (Botha 2004). It was adopted by the workshop.

\section{A UNITED MINISTRY FOR SERVICE AND WITNESS (2006)}

During the last couple of years the DRC entered a process of restructuring its work on general synod level. Although the general synod's agenda should cover the whole field of the church's ministry, it was accepted that the functions on general synod level should be distinguished from that of regional synods, presbyteries and local congregations. The general synod's function is to advise synods, take responsibility for research, planning, coordination, information, guidance and liaising and it may, in the execution of its tasks and in cooperation with synods, launch projects in order to stimulate the actions of synods and congregations. Apart from these functions of general synod, three dimensions or focus areas in the ministry of the church can be differentiated, but should not be separated from each other: the vertical focus on God (worship, confession, etc), a focus on the ministry within the congregation (equipping members, pastoral care, youth work, etc) and a focus on the world (witness and service). This model for structuring the ministry of the church, which was originally adopted by the leadership in URCSA, influenced the thinking in the joint process. The formation of the Kaapse Getuieninsaksie (KGA) - the united structure for service and witness in the Cape Synods - also served as an example to the national process. The core ministry of the church should therefore be structured in such a way as to reflect the three dimensions. Apart from these core ministries, there should also be supporting structures, taking care of finances, church order, theological training, etc. The commissions for service (diaconate) and witness (mission) were consequently structured in one ministry, focussing on reaching out - focussing on the world.

The realisation dawned that service and witness not only belong together for practical reasons, but also in principle. It is not possible to separate the two, neither in principle nor in practice. This reality needed to be reflected in the structuring of the church's ministry. Firstly, the merging of the service and witness functions into one structure had to be implemented in all the domestic churches of the DRC Family. After that process had been completed, a meeting of representatives of the ministries for service and witness of the respective churches were convened in October 2006. The respective ministries for service and witness of the four churches could eventually become one, united body. A new constitution was adopted for the "United Ministry for Service and Witness". From now on the four churches, still in the process of reunification, already started sharing one agenda and joining activities on general synod level. This could only have happened after a breakthrough in the deadlock in the unity process during August 2006, where the leadership of all four churches recommitted themselves to covenant for the re-unification of the family.

\section{A NEW UNDERSTANDING OF THE CALLING TO SERVICE AND WITNESS IN UNITY}

In a preamble to the constitution for this newly formed unity structure for service and witness, a new understanding of the calling to service and witness in and from southern Africa was formulated and adopted. This formulation resulted from an intensive process of discussion and reflection by the executive committee of the United Ministry for Service and Witness. During a retreat at Achterberg in 2006 all the biblical texts quoted in the document were read and reflected upon by a task group consisting of Johan Botha, Willie van der Merwe, Carl Swart, Hennie van Deventer, Andries Hoffman, Victor Pillay and Gideon van der Watt. During the first 
official meeting of the United Ministry for Service and Witness, convened at the Roman Catholic Church's Good Sheperd Retreat near Hartbeespoortdam, under the joint chairmanship of Piet Meiring and Jimmy de Wet, representatives of all synods of the participating churches adopted the declaration. But that only happened after the document had been carefully reviewed again. It really became a joint effort, a historical event celebrating the culmination of a long process of coming together again, at least in terms of the DRC Family's calling to witness and service. The document was built on the 2004 declaration, deliberately defining the church's mission (mission ecclesiae) in the mission of the Triune God (missio Trinitatis Dei), in the love, care and unity flowing from the being and the acts of the Triune God. Mission (service and witness as two sides of the same coin) was understood as a holistic calling, a being in the world, but also an active service in love and a united witness about the faith in Christ as Saviour and King. Mission was to be done through the different modes of being/living before God (coram Dei), through worship and intercession, kerugma, diakonia, koinonia, but also by seeking justice, healing and reconciliation and being involved in the responsible conservation and cultivation of nature. The importance of continuously discerning the challenges posed by the southern African context, as well as the church's calling to public witness was stressed. Mission was not only primarily the calling of congregations, but also of the many other modes of being church. Mission in unity and unity in mission was of utmost importance.

Since the formation of the United Ministry for Service and Witness, this new structure focussed on several projects: working with overseas partner churches (USA, Germany and the Netherlands), on several diaconal projects, on the reception of the Accra declaration, on enhancing intercultural exchange programs amongst youth, violence in our society and possible ways of enhancing reconciliation, on the functioning of a joint HIV Aids forum, literature, ecology, public witness, etc.

In September 2009 a conference, in which representatives of the broader DRC Family of Churches (including the sister churches from Botswana, Zambia, Zimbabwe, Malawi, Lesotho, Namibia, Nigeria, Mozambique, Kenya and even Angola and the Democratic Republic of Congo) partook, was convened. The theme was "mission in partnership", focussing on guidelines, values and the role of leadership in working in partner relationships in our Southern African region. Mission was increasingly understood in terms of relationship (koinonia) and unity, mutuality and respect, collaboration and fellowship.

However, the loss of momentum in the domestic unity process and the deterioration of relationships between leaders hampered the realisation of a legitimate and credible mission in unity. Disunity in the DRC Family remains the biggest stumbling block in coming to a credible participation in God's mission in our southern African context

\section{MISSIONAL CHURCH - YET ANOTHER APPROACH?}

The South African social, economical, political and cultural context changed dramatically since the emergence of the new democratic dispensation in the 1990's. It occurred simultaneously with other significant global changes apparently only "arriving" in South Africa since 1994: increasing secularism, the phasing in of post-modern thought- and value systems, the dawn of a post Christendom era which also entailed the decline in western mainline churches and the southward shift to what Philip Jenkins call "New Faces of Christianity" (Jenkins 2006, see also Sanneh 2008). Many members of the DRC Family emigrated overseas or inwards, into new forms of laager. These developments put many congregations of the DRC (and our sister churches) under pressure: it became a struggle just to survive or to maintain what was left of the ministry. It became clear that a new vision of identity and calling - especially of local congregations - was of utmost importance. 
From a fresh angle, this time the practical theology and congregational studies, a new missional movement or partnership was established. The South African Partnership of Missional Churches came into being, focussing mainly on the missional identity and calling of local congregations. This South African movement was strongly influenced by developments in North America, like the Gospel and our Culture Movement, publications on the new concept of missional church by theologians like Darrel Guder, Graig van Gelder, DJ Hall, Allen Roxburgh, Scott McKnight and Pat Keifert, as well as theologians reflecting on the emerging church movement like Rob Bell and Brian McLaren. Leading role-players in South Africa were, amongst others, Frederick Marais, through Communitas and the SAPMC, Jurgens Hendriks through NetAct and post graduate training programs and Nelus Niemandt by the publication of his book on the emerging churches movement (Niemandt 2007). Lesslie Newbigin and David Bosch, however, remained the two most influential theologians and guiding lights in this movement.

The essence of the movement lied in the refocusing on the Triune God and the church's participation in the missio Dei. It also focussed on the missional nature of the church - especially the local congregation. In this missional ecclesiology there was a clear theological shift from a functional approach (mission as one aspect of the church's ministry) to a foundational approach, based on the church being an agent of the missio Dei and deliberately and essentially missional in all aspects of the understanding of the church and its ministry. Miroslav Volf's work "After our likeness: the church as the image of the Trinity" (1998) played a key role in defining this emphasis on the Trinity (Hendriks 2008:3). Another key concept in this movement was the discernment journey in which congregations were guided by dwelling in the Word, especially Luke 10:1-12. The rediscovering the narratives of the early church (the Book of Acts) and the similarities of these contexts to our own situation were also evident. This strategy of discernment coincided with a "season of listening" announced and implemented within the Dutch Reformed Church since 2008 and which is entering a second phase of "listening across boundaries" during 2010

\section{TWO DIFFERENT CONCEPTS AND APPROACHES?}

It remains a question whether we have had in these latest two movements within the DRC Family, namely the program of the United Ministry for Service and Witness on the one hand and the Partnership of Missional Churches on the other hand, two different concepts of and approaches to the missionary task of the church, or whether it merely represented different focus areas in the ministry. The Ministry for Service and Witness clearly focused on a broader field - on denominational work (institutional) as well as the calling of congregations, on partnerships with other churches, on the church's public witness, on projects and programmes, on evangelisation and diaconal service - in the local environment, but also further a field. Its focus was also clearly on the African context, which is neither necessarily post-modern nor post-Christendom. The Missional Partnership, on the other hand, focuses mainly (although not exclusively) on local congregations, on transforming their identity, on being missional within the local context and not so much on missionary or diaconal programs and actions. The missional movement ventured to find answers for a new generation in a post-modern, secularised society - thus the connection to the emerging church movement in Northern America.

At the 2010 annual theological workshop of the Southern African Missional Society this discourse was taken up again. The debate and creative tension between these two approaches were a healthy development. Currently, there is also a venture to integrate the different approaches into one integrated and all- encompassing "missional ecclesiology" for the DRC family. This poses new challenges. Asking the following questions could be fruitful in the continuous discourse. 


\subsection{Missio Dei as overarching principle in understanding church?}

Participating in the missio Dei as the overarching concept describing the task of the church and formulating a missional ecclesiology is often emphasised. Missio Dei is indeed an important attribute or facet of the essence of the Triune God. But is it all there is to God and our relation to God? The notion of just coming, being or living in God's presence, coram Dei, or worshipping and celebrating communion with God, only to the glory and in celebration of God's goodness and beauty - the movement towards God and not only God's movement towards the world - is just as important. Could mission or participating in the missio Dei therefore be described as the overarching or only task of the church, as is often done in the venture to formulate an overarching missional ecclesiology for the DRC? There is a well known saying: "if everything becomes mission; nothing is mission any more". HW Gensichen's (1971) differentiation between missionary dimension and missionary intention remains helpful. Although there should be a missional dimension to everything the church does, not everything is or could intentionally be missional. By dissolving church in the apostolicity of the church, like in the post Second World War "Apostolaatstheologie" of Hoekendijk and Van Ruler, in activity in the world, for the sake of the world, with the Spirit reduced to the wind in the sails of this activity of the church, the dangers of eroding the term mission as well as church are obvious, not to mention our concept of the Triune God.

In the focus on witness and service, the missional dimension in the liturgy (worship services) is for instance still to be considered properly. The worship service - and especially the Lord's Supper - remains the heartbeat of being church, the centre for changing and equipping and sending out the members and body of faithful as missionaries into the world. But is liturgy merely a missional activity, merely a preparation for the liturgy in the world? The interconnection between mission and liturgy (and the missional dimension of liturgy) needs further reflection.

\subsection{New missional language for the African context?}

Is the term "missional", instead of missionary, a new discovery (a recent American invention) or is it merely new language (Saayman 2010) for old concepts that existed for many years in the discourse on mission? Continuity with the historical discourse in mission is important. There is indeed a danger in borrowing too much from North American theologians and post-modern, Western contexts. The African Initiated Churches, for instance, are essentially missional without consciously knowing or understanding or participating in this missional discourse and language. The importance of African interlocutors in this discourse and a serious engagement with the African context, which is not necessarily post-modern or post-Christendom, is evident.

\subsection{Discernment, texts and hermeneutics?}

An important facet in the program of the Partnership for Missional Congregations is discernment - discerning where God is already working and then partaking in that action. A question would be: what criteria are used to measure or discern where God is working? On what basis are specific texts selected, for example Luke 10 or John 4, for the "dwelling in" process during this prolonged season of discernment exercises?

\subsection{Focus on congregations?}

The focus on congregations is a healthy reaction to the era of denominational or institutional service and witness, but it could also be one-sided. There are other modes of being church as well. Dirkie Smit (2003:55-77) distinguishes at least six such concrete, visible, social forms of the real church, namely worship (1) and the local congregation (2), denominations (3) and the ecumenical church (4), individual believers (5) and voluntary initiatives and activities (6). Is this radical focus on only congregations helping us in the search for greater denominational 
unity? What about the programmes (ecology, public witness, ecumenical relations, etc), that can only be implemented on a denominational and national level, and the importance of only really discerning God's will by recognising and partaking in the "catholicity" of the church? "Being" missional is indeed important, but so is "doing" mission, also in a structured way and even from an institutional or denominational point of departure. It is thus a question whether it is viable to formulate a missional ecclesiology, based on this exclusive focus on "being missional congregations" as the overarching or all inclusive principle for the whole ministry of the church.

The South African Partnership for Missional Churches is indeed bringing about welcome change in the participating congregations and the way these congregations perceive themselves as being sent. This honest and sincere engagement, the rediscovery of discernment (listening anew and with others and across borders) and the focus on being missional instead of only doing mission, is to be applauded and supported. It is a well thought trough program (with insights borrowed from social sciences) and it is practically implemented. The question remains whether the United Ministry for Service and Witness, with all its reflections and efforts, are making any meaningful impact on the practical ministry of congregations, individual members and in the southern African society? Is the denominational approach to mission and the way it is structured in the still divided Dutch Reformed Family of Churches valid or effective?

The search for a proper missional or missionary understanding of the church's identity and calling continues. The declaration by the United Ministry for Service and Witness on "Our Calling to Service and Witness in Unity" can be helpful in this discourse.

\section{OUR CALLING TO SERVICE AND WITNESS IN UNITY}

\section{The mission of the Triune God}

1.1 The Church's calling to service and witness in unity flows from the being of the Triune God. The very life of God is characterised by covenant, reaching out, self-communication, mutuality, relation and unity - God is love (Deus caritas est), seeking communion. The acts of God, as revealed in creation, scripture and throughout history, are characterised by God's love for the world, inviting people to enter a new world, a Trinitarian space, where the God of communion extends hospitality and care and makes all things new (missio Trinitatis Dei).

1.2 The mission of service and witness expresses God's love and compassion to bring salvation in all its dimensions (shalom) to all people and the whole of creation. (Ex 3:7-8, Ex 19:5-6, Ex 34: 6-9, Ps 146: 6-10, Luke 4:18-19, John 17:11, 17, 20-23, Matt 28:18-20, John 20:21-22, Acts 1:8, 1 John 4: 7-21, Eph 4:17, Rev 21:5)

\section{The mission of Christ}

2.1 The Father has sent the Son into the world to gather God's church from all the nations and to send us into the world in the power of the Holy Spirit. (John 3:16-17, John 20:21-22)

2.2 The salvation that Christ achieved is all-encompassing. It includes the forgiveness of our sins, our liberation on all levels of life as well as the liberation of creation. God's salvation of the world is realised in that He builds his kingdom here and now. This kingdom will, however, only come to full realisation with Christ's second coming, when all things will be new and all nations and people will glorify God. (Ezek 47:12 and Rev 22:2, Rev 21:1-5)

\section{In the power of the Holy Spirit the Church is sent}

3.1 As the body of Christ our Lord and Saviour, the essence of the church is to live as partaker in 
God's mission in this world (mission ecclesiae). The local congregation as primary agent of God's mission, but also the church as a whole and all its members, are under the commission of God. Dependent on and guided by the Holy Spirit, we are called as prophets, priests and kings, to:

- $\quad$ Live in the presence of God (coram Dei), obedient to the word of God,

- A ministry of worshipping God and praying for the world (leitourgia),

- Minister the Gospel of God's salvation to all people through word (kerugma), deed (diaconia) and in a relationship of love and unity (koinonia),

- $\quad$ Seek justice, reconciliation and healing, testifying to the hope that we live by and

- Conserve and cultivate creation in the name of God and for the sake of all who live in it.

This we do with the deepest motive of glorifying God and in service of the coming of the kingdom (Rom 12:1-2, Eph 1:10 ff). (Matt 4:23-25, 5:13-16, 9:35-38, 10:7-8, 28:18-20, Luke 6:17-19, 9:1-6, 10:25-37, John 20:19-22, Acts 1:8, Heb 3:1, 1 Pet 2:9-10, 1 Pet 3:15)

3.2 The mission of service and witness occurs where we as the church, in the power of the Holy Spirit, with integrity, in obedience and in following Christ, with compassion and in serving others, in humility but also in boldness, witness about God's love for the world. In reaching out to all people, new borders are continuously crossed and service and witness are not to be separated.

3.3 We are called to service and witness in and from Southern Africa, by

- $\quad$ Prayerfully, and with others, discerning and obeying God's calling for us in and from this context,

- Listening with compassion to the voices crying out for deliverance from sin, enslavement, fear, hunger, sickness, pain, violence and injustice - the suffering in all its dimensions,

- Being a prophetic voice and of service in alleviating the need of people in all communities,

- Respecting, building, celebrating the good in our rich and diverse heritages, cultures, languages, gifts, contributions and the vast potential in all the people of Southern Africa,

- $\quad$ Entering into meaningful partnerships with other churches, ecumenical bodies and governmental- and non-governmental institutions and

- Witnessing to our faith in the Triune God through respectful dialogue with people of other faiths and convictions.

3.4 As the legitimate bearer of this Good News (Gospel), the church of Christ is to be one and to live and work in the likeness of the one triune God, Father, Son and Holy Spirit. "As prisoner for the Lord, then, I urge you to live a life worthy of the calling you have received. Be completely humble and gentle; be patient, bearing with one another in love. Make every effort to keep the Unity of Spirit through the bond of peace. There is one body and one Spirit - just as you were called to one hope when you were called - one Lord, one faith, one baptism; one God and Father of all, who is over all and through all and in all." (Eph 4:1-6)

\section{BIBLIOGRAPHY}

Adonis JC, 1986, Die Sendingbeleid van die Nederduitse Gereformeerde Kerk - 'n Kritiese Evaluasie, in Robinson en Botha, 1986, Wat is Sending? - 'n werkswinkel vir die familie van NG Kerke, UWK Bosch DJ, 1991, Transforming Mission, Paradigm Shifts in Theology of Mission, New York: Orbis Bosh DJ, 1986, Sending, 'n prinsipiële besinning, in Robinson en Botha, 1986, Wat is Sending? - 'n werkswinkel vir die familie van NG kerke, UWK

Botha J, 1986, Die sending van die NG Sendingkerk in Suid Afrika - 'n Bestekopname en 'n

Toekomsperspektief, in Robinson and Botha (eds), 1986, Wat is sending -'n werkswinkel vir die familie van NG kerke, UWK 
Botha J (ed), 2004, Declaration on our calling to witness in and from Africa, Unpublished report of the Mission Conference for the DRC Family, Stellenbosch

Botman R, 2004, Mission from the African Soil, Unpublished paper read at the Mission Conference for the DRC Family, Stellenbosch

Crafford D, 1982, Aan God die dank 1, Pretoria NGKB

Crafford D (ed), 1991, Trailblazers of the Gospel. Black Pioneers in the Missionary History of Southern Africa, Institute for Missional Research, University of Pretoria

Cronje JM, 1981, Aan God die dank 2, Pretoria, NGKB

Church and Society, 1990, Dutch Reformed Church General Synod

Gensicehn H-W, 1971, Glaube für die Welt, Gütersloh: Gerd Mohn.

Hendriks HJ, 2008, Trauma and conflict as prerequisites for identity transformation: lessons from the South African Partnership for Missional Churches, paper read at Religious Research Assosiation 2008 Annual Meeting October 17-19, Louisville Kentucky www.ngkok.co.za/hjh-sapmc.pdf - accessed 11.26. 2009 Jenkins P, 2006, The New Faces of Christianity - believing the Bible in the Global South, Oxford University Press.

Kinghorn J (ed), 1986, Die NG Kerk en Apartheid, Macmillan SA

Kritzinger Dons, 2002, No quick fixes, the challenge of mission in a changing South Africa, IMER

Loubser JA, The Apartheid Bible, A Critical Review of Racial Theology in South Africa, Maskew Millar Longman

Meiring PGJ, 1989, "Your will be done: Mission in Christ's way", Discerning God's will for mission in South Africa ... tomorrow, Missionalia 18(1), 248-258

Nel M, 2009, The emerging missional church, in Du Plessis, Orsmond and Van Deventer (ed's) Missionary Perspectives in the New Testament, Bible Media, Wellington

Nel R and Du Toit H (eds) 2007, Ons Pelgrimstog na Eenheid/Our Pilgrimage to Unity: conversations on healing and reconciliation within the Dutch Reformed Church Family, University of Pretoria

Pauw CM, 2004, Our joint calling in Africa - witness in unity, unpublished paper read at the Mission Conference for the DRC Family, Stellenbosch

Robinson PJ, 1986, Mattheus 28:16-20 in die ontwikkelende sendingdenke van die Nederduitse Gereformeerde Kerk, in Du Preez et al, (eds) Sendinggenade, Kaapstad, NG Sendinguitgewers, p86-101

Robinson PJ and Botha J (eds), 1986, Wat is sending - 'n werkswinkel vir die familie van NG kerke, UWK Saayman W, 2003, 'n Nuwe horison - verkenning ten opsigte van 'n sosiale geskiedenis van die Nederduitse Gereformeerde Sending, in Verbum et Ecclesia, Volume24(1), 2003

Saayman W, 2007, Being Missionary - Being Human. An overview of Dutch Reformed Mission. Pietermaritzburg: Cluster Publications

Saayman W, 2010, Missionary or missional? A study in terminology, in Missionalia, Vol 38, No 1, April Sanneh L, 2008, Disciples of all nations - Pillars of world Christianity, Oxford University Press.

Smit, DJ, 2003, "On learning to see? A Reformed perspective on the church and the poor," in Suffering, Poverty, and HIV-AIDS: International Practical Theological Perspectives, edited by Pamela Couture and Bonnie J. Miller-McLemore, Cardiff Academic Press, 55-70.

Strydom JG, 1939, Ons Sendingbeleid van Apartheid, in Die Basuin, 10 - 4 (August), p.1-2

Strydom JG, 1946, Die Rassevraagstuk en die Toekoms van die Blankes in Suid Afrika, NG Kerk OVS

Van Aarde, B, 2003, Woelinge in die barmhartigheidbediening van die NG Kerk 1962-2002 -'n kerkhistoriese oorsig, in Coertzen P (ed), 350 Years Reformed, CLF, p 411-429

Van der Merwe, WC, 2004, Geroep om te dien: Suider Afrika en al sy mense -'n perspektief op die implementering van die NG Kerk se Verklaring (2002), NGTT, 45 (2), p428-438

Van der Watt, G, 2003, Die Sendingpraktyk van die Ned Geref Kerk: Enkele tendense vanaf 1952 tot met die eeuwenteling, Verbum et Ecclesia, 24 (1), 5, p213 -231

Van Niekerk, AS, 1997, Einde of begin vir die NG Sending?, NGTT 38(4), 408-416

Van Niekerk, AS, 2002, Ons geestelike toerusting vir missionêre diakonaat in kultuurkonteks, NGTT 43 (3\&4), p616-630

Venter R, 2004, Trinity and mission, challenges to a reformed witness in Africa today. Verbum et Ecclesia, 25 (2), p751-768

Volf M. 1998, After our likeness: the church as the image of the Trinity, Eerdmans, Grand Rapids 


\section{KEY WORDS}

Dutch Reformed Church Family

missio Dei

missional congregations

witness and service

\section{TREFWOORDE}

Nederduits Gereformeerde Kerk Familie

missio Dei

missionale gemeentes

getuienis en diens

Dr G van der Watt

Navorsingsgenoot: Departement Missiologie

Fakulteit Teologie

Universiteit van die Vrystaat

Bloemfontein

9300

E-pos: Getuienis@ngkerkovs.co.za 